UDC 663.25.013:005.332.4

DOI: 10.15673/fie.v10i3.1059

\author{
Braiko M. \\ Assistant \\ Department of Marketing, Business and Trade \\ E-mail: marina.g.braiko@gmail.com \\ Golubyonkova $\mathbf{O}$. \\ Ph.D., Associate Professor \\ Department of Marketing, Business and Trade \\ Odessa National Academy of Food Technologies \\ Kanatna str., 112, Odesa, Ukraine, 65039 \\ E-mail: lena.golubenkova@gmail.com
}

\author{
Solodova 0. \\ Postgraduate \\ Department of Marketing, Business and Trade \\ E-mail: o.solodova@shabo.ua \\ Braiko A. \\ Undergraduate \\ Department of Tourism and Leisure \\ Erasmus Mundus on Wine Tourism Innovation \\ University of Rovira I Virgili \\ C/ Marcel-lí Domingo, 1, Tarragona, Spain, 43007 \\ E-mail: braikoanastasiia@gmail.com
}

\title{
CREATION OF LOCAL WINES AS A METHOD OF FORMATION OF COMPETITIVE ADVANTAGES OF THE WINERY
}

The article proves the practicability of producing wine from local grapes for Ukrainian wineries. The substantiation is based on the construction of five levels of goods and consumer values. The fifth level is a wine that has a unique style: its character, temperament, expresses the peculiarities of the area where it is produced. It has directed therapeutic properties due to the maximum content of nutrients from certain varieties of grapes and innovative technology. A business model of wine production in the chateau format has been proposed. The mission, goals and strategies for such production have been developed. The mission is the production of unique wines and the revival of winemaking traditions and wine consumption culture in Ukraine. Target audience of consumers and competitive advantages have been determined. It is advisable to determine a competitive strategy for focusing on the manufacture of local wines. The marketing strategy of growth has been proposed - the strategy of developing a new product. Namely - the organization of a full production cycle for the manufacture of dry white table wines from the grapes of the new breeding generation by author's blend schemes. Market research has shown that production of local wines may become a competitive advantage of Ukrainian winemakers for a rather long period of time. The competitive advantages of "Chateau", which produce local wines, allow us to work effectively on the national and international markets. petitive.

Keywords: Ukrainian enterprises, consumer value, local wines, business model of chateau, com-

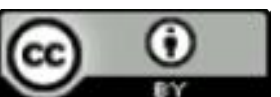

This work is licensed under a Creative Commons Attribution 4.0 International License http://creativecommons.org/licenses/by/4.0/

Statement of the problem and its connection with important scientific and practical tasks. According to the annual report of the International Organization of Vine and Wine, the current stage of development of world wine production shows orientation towards new winemaking markets and shows the steady consumer interest in local wines made from local (indigenous) grape varieties. Ukraine has a great potential for production, which will reflect a unique style of wine. However, the Ukrainian ampelographic heritage is represented exclusively by introduced varieties (transferred from another area to this territory): historically the wine regions were parts of different countries, inhabited by different nations with a diametrically opposite attitude to the wine culture, which explains the deficit of indigenous technical grape varieties in these territories.

The current state and prospects for the development of the wine-growing and wine-making industry in Ukraine allow and suggest the improvement of the grape range by means of the use of varieties of a new breeding generation and clones of classical varieties.

In the conditions of European integration and the absence of significant competitive advantages over European products, it is necessary to create a new competitive product that would reflect the nature and features of the Ukrainian vine and territory and could become a "Ukrainian brand". Consequently, the creation of terroir wines or local wines (wines of the specific territory) made of grape varieties which are the most suitable for the Ukrainian region has been suggested in this study. The need for a systematic study of these problems, their topicality and practical significance determined the choice of the topic of the research.

The analysis of the latest publications on the problem. The various business models of winemaking business have been examined in the studies of many scholars. The advantages of investing in winemaking businesses of different sizes in France, Italy, the USA and Romania have been considered in the studies [1-3]. The models of winery management in Chile have been ana- 
lyzed in the study [4]. The analysis of efficiency of wine production within the framework of several models by the example of Italy has been carried out in the study [5]. The special attention to the study of marketing strategies for small winemakers and producers of mass wine has been paid in the scientific work [6]. The methodology of constructing a business model that underlies our study has been presented in the work [7].

Forming of the aims of the research. The aim of research is the development of an effective business model of wine production using the principles of marketing. To solve the tasks, the following methods are used: analysis and synthesis, logical generalization, analogies, competitive comparison.

Giving an account of the main results and their substantiation. According to F. Kotler's concept, the product is considered as a five-level system that creates a hierarchy of consumer value, wherein each subsequent level raises the consumer value of the product. Five levels of the product: 1) key value; 2) main product; 3) expected product; 4) improved product; 5) potential product.

In order to determine the ways of formation of competitive advantages the five levels for the product category "wine" are examined (Table 1).

Table 1

Hierarchy of consumer value of still wines*

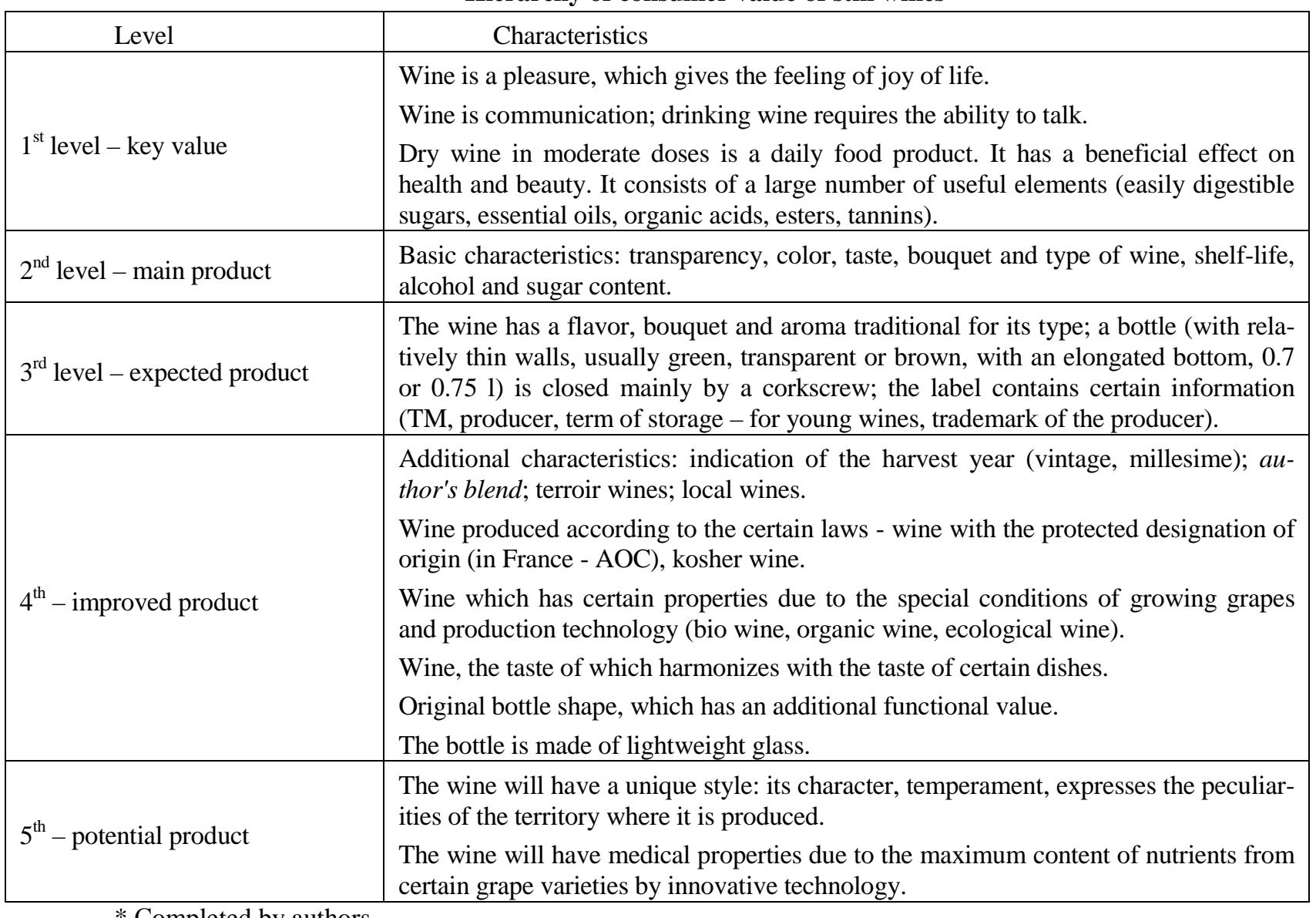

* Completed by authors

The culture of wine consumption implies creation of a friendly atmosphere for easy-going conversation. The tradition of family lunch or family dinner accompanied by wine is still preserved in countries with high level of wine consumption.

The benefits of wine for health have been examined by ancient doctors and modern scientists continue to argue about this fact. Moderate use of wine improves appetite, strengthens the whole body, improves sleep, dilates the blood vessels, slows the aging process, enhances the body with antioxidants and vitamins, stabilizes the acidity of the stomach, prevents oncological diseases and is considered to be an excellent anti-stress medica- tion.

Nowadays as a rule the competition is held at the fourth level in the developed countries - at the level of search for additional benefits, and in less developed countries - at the level of expected product. It should be remembered that the additional benefits will become soon expected. It means that in order to distinguish themselves the competitors will have to look for even more new benefits and characteristics that will be able to become their competitive advantage for a certain period of time.Consequently, the production of local wines may become a competitive advantage of Ukrainian winemakers for a rather long period of time. 
Nowadays in the conditions of fairly aggressive global competition each country is re-evaluating its grape variety resources in a new way. In this regard in most cases the preference is given to its own aboriginal (indigenous) and breeding varieties. Despite the fact that winemaking in the territory of modern Ukraine appeared in the IV century BC on the southern coast of the Crimea, historically it happened that wine-growing regions were part of different countries, were inhabited by different nations with the opposite attitude to the wine culture. This explains the shortage of aboriginal grape varieties in these territories, including in the Odessa region, where the only autochthonous variety is Telty Kuruk, which is recognized as the pride of the shabo terroir whereas the ordinary dry wine of the PDO (Protected designation of origin) "Telti-Kuruk Shabo "(LLC "PTC Shabo", Odessa) received the Grand Prix at the international tasting competition "Yalta. Golden Griffin 2013" in July 2013 [13].

Telti-Kuruk is a unique grape variety, firstly planted in Shabo during the Turkish rule. In the translation from the Turkish the name of grape variety means "fox tail". The grape variety received its unusual name through a specific shape of a cluster that resembles a fox tail. Beside the company "Shabo", the wine from the Telty Kuruk variety is released by another company "Beykush Winery". There is the wine called "Beykush TelltiKuruk 2012" in the range of company's products. Produced from the local grape variety these wines have the full right to be called local wines.

The correct wine making implies the cultivation of the right grape. Local wine can be made exclusively from the grapes which belong to the winery. And nowadays it is possible to name a number of Ukrainian wineries where the author's wines and wines that can be attributed to local wines are produced. Among such wines there are TM Kolonist Ivan Plachkov (Odessa region), LLC "Industrial and trading company Shabo", TM "Winemaking farm Prince P.N. Trubetskoy" (Kherson region), TM "Wines of the Guliyev" Robert Guliyev (Odessa region), TM "Beykush Winery".

Table 2 presents consolidated and systematic information on key indicators of Ukrainian enterprises.

Table 2

Analysis of Ukrainian enterprises by key indicators (2018)*

\begin{tabular}{|l|l|l|l|l|c|}
\hline \multicolumn{1}{|c|}{$\begin{array}{c}\text { Name } \\
\text { of the enterprise }\end{array}$} & \multicolumn{1}{|c|}{$\begin{array}{c}\text { Production } \\
\text { volume }\end{array}$} & Vineyards, ha & Price, UAH & \multicolumn{1}{c|}{$\begin{array}{c}\text { Channels } \\
\text { of distribution }\end{array}$} & $\begin{array}{c}\text { Presence of the } \\
\text { certificate for } \\
\text { wholesale com- } \\
\text { merce }\end{array}$ \\
\hline $\begin{array}{l}\text { LLC "Industrial } \\
\text { and trading } \\
\text { company Sha- } \\
\text { bo" }\end{array}$ & $\begin{array}{l}50 \text { mln of bottles } \\
\text { of still wine } \\
\text { (12 th of bottles } \\
\text { "Shabo Reserve") }\end{array}$ & $\begin{array}{l}1200 \text { ha (70 ha } \\
\text { Telti-Kuruk) }\end{array}$ & $\begin{array}{l}\text { From 150 UAH } \\
\text { ("Shabo Re- } \\
\text { serve") }\end{array}$ & $\begin{array}{l}\text { Wines are presented in } \\
\text { more than 47000 stores } \\
\text { in Ukraine }\end{array}$ & + \\
\hline $\begin{array}{l}\text { "Vintrest" } \\
\text { liyev") }\end{array}$ & $\begin{array}{l}200-240 \text { th of bot- } \\
\text { tles }\end{array}$ & 1000 ha & $80-250$ UAH & $\begin{array}{l}\text { In supermarkets and } \\
\text { restaurants }\end{array}$ & + \\
\hline $\begin{array}{l}\text { OJSC "Prince } \\
\text { Trubetskoy" }\end{array}$ & 100 th of bottles & 200 ha & $100-600 \mathrm{UAH}$ & In supermarkets & + \\
\hline $\begin{array}{l}\text { "Beykush } \\
\text { Winery" }\end{array}$ & 17 th of bottles & $220-400 \mathrm{UAH}$ & $\begin{array}{l}\text { In specialized wine } \\
\text { shops }\end{array}$ & + \\
\hline "Kolonist" & 200 th of bottles & 30 ha & From 150 UAH & $\begin{array}{l}\text { In supermarkets, res- } \\
\text { taurants, hotels, night } \\
\text { clubs }\end{array}$ & + \\
\hline
\end{tabular}

*Designed by author based on data from official sites of the companies [9-13]

The outline business model of Alexander Osterwalder [7] is used to form the basic principles of the creation, development and successful operation of the organization. The business model template consists of 9 blocks (Fig.1) based on value offers for consumer segments that is what we call the competitive advantages of the enterprise.

Table 3 provides a developed business model of chateau that will focus on the production of local wines.

The mission is the production of unique wines and the revival of winemaking traditions and wine consumption culture in Ukraine.

The marketing goal is the production and sale of dry white table wines in the amount of 10,000 cases or
120,000 bottles of 0.75 liters per year.

The basic strategy of development: the strategy of product differentiation - ensuring a high and stable quality of wine as a result of the organization of the company of "chateau" type and the use of a unique coupage of stably productive, high-quality and high-tech grape varieties adapted for cultivation in the Odessa region. of local wines.

Competitive strategy: focusing on the production

Marketing strategy of growth: the strategy of product development - the organization of a full cycle of the dry white table wine production from the grapes of the new breeding generation by the author's coupage scheme. 


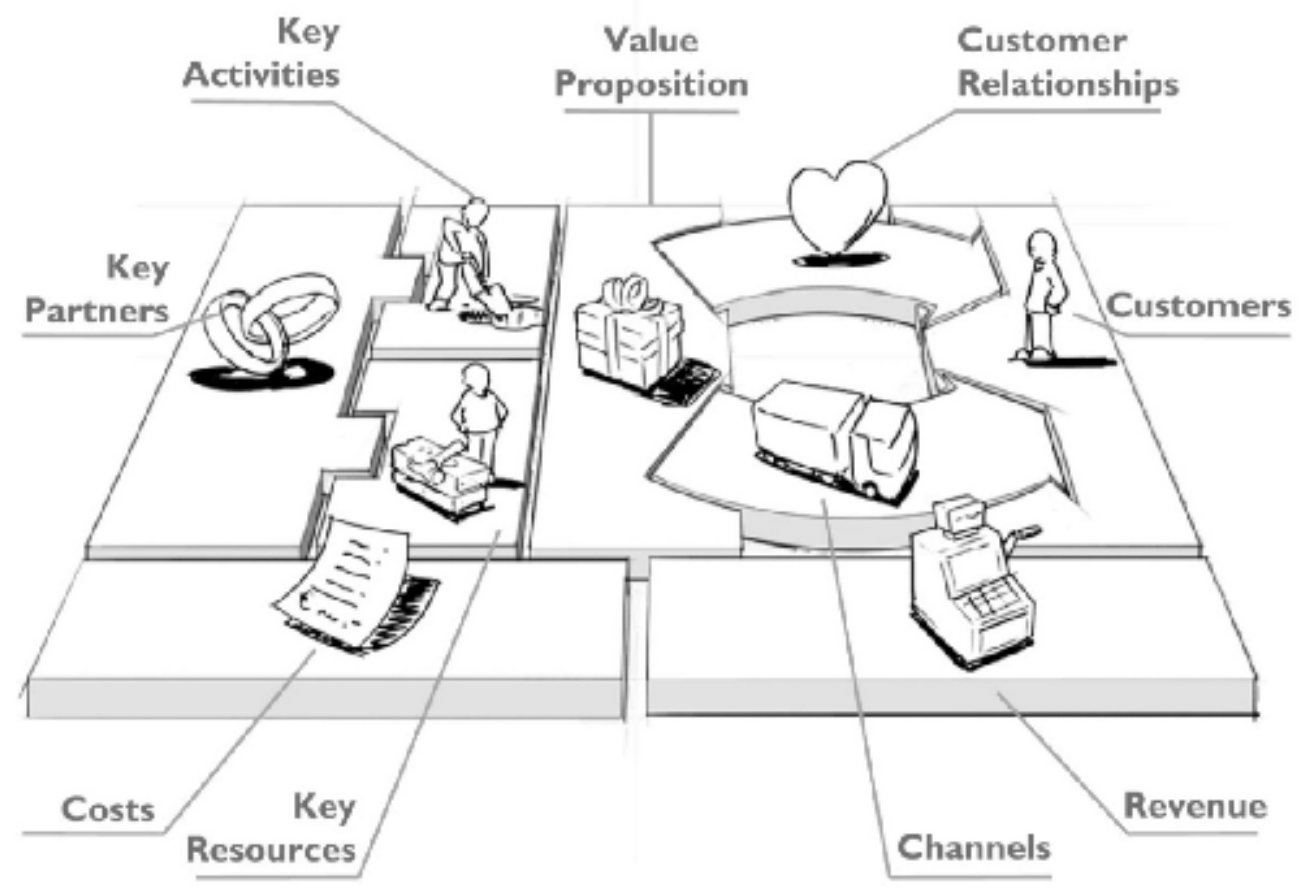

Fig. 1. Business model template of A. Osterwalder [7]

Business model of chateau according to the template of A. Osterwalder*

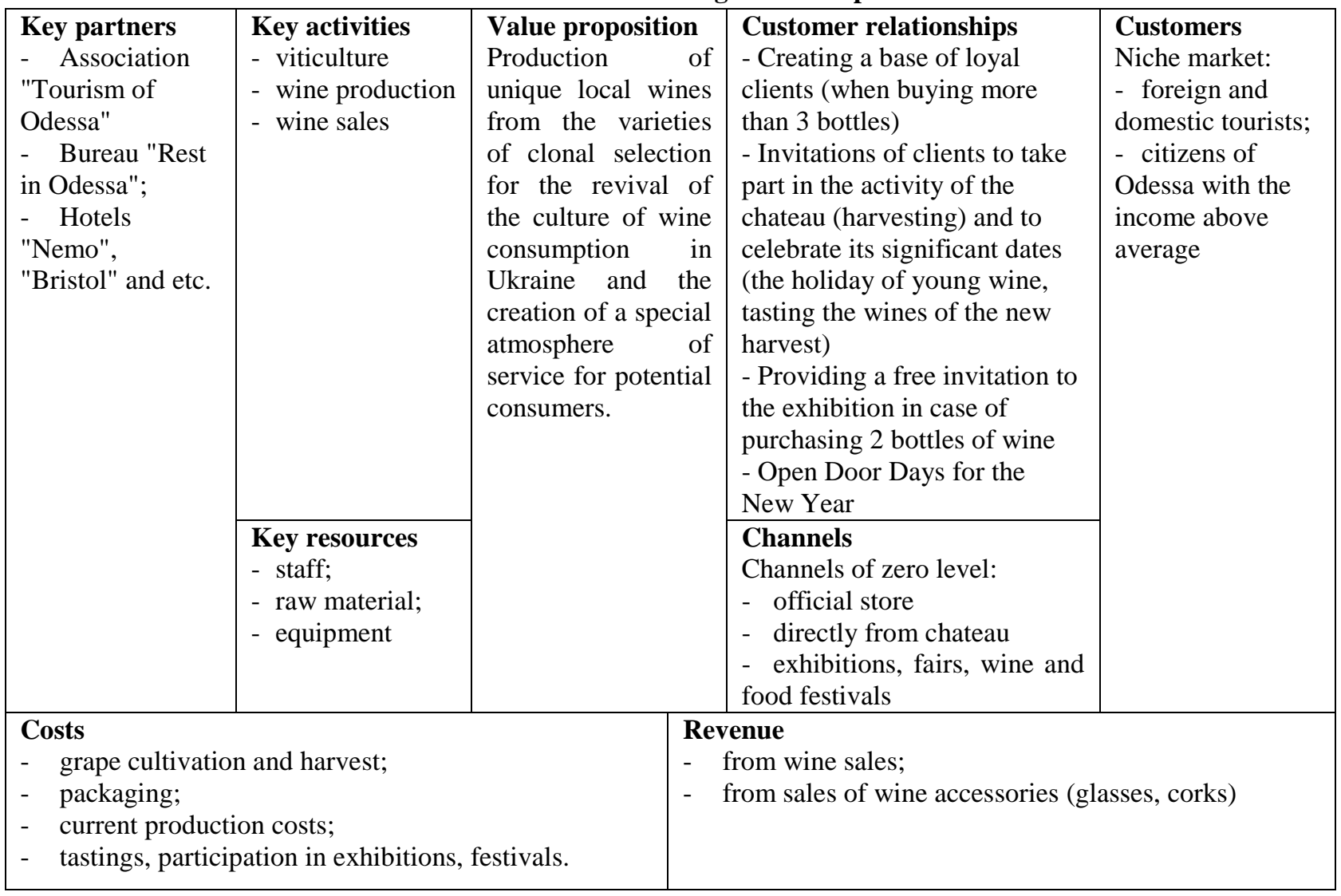

*Completed by authors 
Target segments: 1) foreign tourists visiting Odessa with the purpose of cultural and / or wine tourism; 2) citizens of Ukraine who come for summer vacation to the Odessa region; 3) citizens of Odessa with the level of income "average", "medium +", "high".

Competitive advantages of "chateau", which produces local wines:

1. Product quality control, which becomes possible due to the small volumes of production and own vineyards. The enterprise becomes more transparent and open to consumers;

2. New service: pre-sale acquaintance of the consumer with wine, its variety and taste diversity due to the explanations of wine consultant and wine tastings;

3. It allows consumers to feel like a winegrower and to become involved in the process of wine making: participation in harvesting, creation of blend wine, celebration and tasting of young wine, etc.;

4. Exclusive high quality wine, which the consumer can try and buy only in official stores or directly at the enterprise. They are created for selected wine connoisseurs;

5. It satisfies the preferences of foreign and Ukrainian wine tourists, thereby strengthening the competitive position of Ukrainian wine.

Conclusions and prospects of the further investigations. The market is moving towards diversity as it is the main factor that determines the scope of consumer preferences in types and styles of wine. There are significant changes in terms of the supply on the wine mar- ket. The modern wine consumer has become more democratic: the consumer understands now the priority of quality over the quantity. If before many consumers favored cheap wines (jug wines), the increase in plantings of precious technical grape varieties contributed to the growth of supply and demand in the international wine market of monovarietal (wines, made from one grape variety). In addition, the consumer "tired" of international varietal wines gives the preference to the indigenous varieties of different territories. According to the majority of experts this very important trend gives the possibility to the development of the original and exclusive winemaking of many countries and regions.

Thus, geographically and historically Ukrainian wines cannot be attributed to the wines of the New World, however, the application of new technologies, innovations, modern trends allow us to choose a strategy for positioning a new wave (new generation) of the wines of the Old World.

Market research has shown that production of local wines may become a competitive advantage of Ukrainian winemakers for a rather long period of time.

The developed effective business model of winemaking production, based on the principles of marketing contains a mission, marketing goals, a common (basic) development strategy, a competitive strategy, a marketing growth strategy, a target segment. The competitive advantages of "chateau", which produces local wines, allow to work effectively in the national and international markets.

\section{References}

1. Beysül Aytaçab, Thi-Hong-Van, \& Hoangab Cyrille Mandouab (2016). Wine: To drink or invest in? A study of wine as an investment asset in French portfolios. Research in International Business and Finance, 36, $591-614$. doi:10.1016/j.ribaf.2015.03.001

2. Beysül Aytaç, Guillaume Coqueret, \& Cyrille Mandou (2018). Herding behavior among wine investors. Economic Modelling, 68, 318-328. doi:10.1016/j.econmod.2017.07.022

3. Nedelcu, A., Tătaru, A., Subić, J., \& Kuzman, B. (2015). The Local Action Group, Local Sevelopment Model based on Community. Case Study-LGA "Land of Vineyards and Wine" Vrancea. Procedia Economics and Finance,(22), 706-715. doi:10.1016/S2212-5671(15)00290-7

4. Schaffernicht, M. FG. (2017). Causal attributions of vineyard executives - A mental model study of vineyard management. Wine Economics and Policy,6(2), 107-135. doi:10.1016/j.wep.2017.09.002

5. Urso, A., Timpanaro, G., Caracciolo, F., \& Cembalo, L. (2018). Efficiency analysis of Italian wine producers. Wine Economics and Policy, 7(1), 3-12. doi:10.1016/j.wep.2017.11.003

6. Hammervoll, T., Mora, P., \& Toften, K. (2014). The financial crisis and the wine industry: The performance of niche firms versus mass-market firms. Wine Economics and Policy, 3(2), 108-114. doi:10.1016/j.wep.2014.11.001

7. Ostervalder, A., \& Pine, I. (2011). Postroenie biznes-modeley: Nastolnaya kniga stratega inovatora. Moskva: Alpina Pablisher.

8. Kotler, P., \& Gertner, D. (2011). In Destination Brands. Oxford: Butterworth-Heinemann.

9. Ofitsiinyi sait "Vyna Huliievykh» (Products «Guliev Wines»). (2018). Retrieved July 16, 2018, from http://www.gulievwine.com

10. Ofitsiinyi sait kompanii «Beykush Winery» (Products «Beykush Winery»). (2018). Retrieved July 16, 2018, from http://www.beykushwinery.com.

11. Ofitsiinyi sait kompanii «Vynorobne hospodarstvo Kniazia P.N.Trubetskoho» (Products «Prince P.N. Trubetskoy Winery»). (2018). Retrieved July 16, 2018, from http://www.vina-trubetskogo.com.ua

12. Ofitsiinyi sait kompanii «Kolonist» (Products «Kolonist»). (2018). Retrieved July 16, 2018, from http://www.kolonist.com.ua.

13. Ofitsiinyi sait kompanii Shabo (Products «Shabo»). (2018). Retrieved July 16, 2018, from http://shabo.ua 
14. Solodova, O., \& Golubyonkova, O. (2017). Research of factors that influence the trademarks policy of an enterprise. Technology Audit and Production Reserves, (38), 34-39. doi:10.15587/2312-8372.2017.119851

15. Braiko, M. H., \& Zhykharieva, N. O. (2017). P'iat rivniv tovaru «vyno tykhe». In Efektyvnist polityky ekonomichnoho zrostannia: Teoriia, metodolohiia ta praktyka (pp. 42-44). Lviv: HO «Lvivska ekonomichna fundatsiia».

Received 3 August 2018

Approved 17 August 2018

Available in Internet 17.10.2018

Брайко М.Г.

старший преподаватель

кафедра маркетинга, предпринимательства

$$
\text { и торговли }
$$

E-mail: marina.g.braiko@gmail.com

\section{Голубёнкова Е.А.}

кандидат экономических наук, доцент кафедра маркетинга, предпринимательства

$$
\text { и торговли }
$$

Одесская национальная академия пищевых технологий

ул. Канатная, 112, г. Одесса, Украина, 65039

E-mail: lena.golubenkova@gmail.com

\section{Солодова О.С.}

аспирант

кафедра маркетинга, предпринимательства и торговли

E-mail: o.solodova@shabo.ua

\section{Брайко A.B.}

магистрант

кафедра туризма и досуга

Эразмус Мундус "Инновации в винном туризме"

Университет Ровира и Вергилия

ул. Хоанот Марторей 15, Вила-сека

Таррагона, Испания, 43480

E-mail: braikoanastasiia@gmail.com

\section{СОЗДАНИЕ ЛОКАЛЬНЫХ ВИН КАК ОДНО ИЗ НАПРАВЛЕНИЙ ФОРМИРОВАНИЯ КОНКУРЕНТНЫХ ПРЕИМУЩЕСТВ ВИНОДЕЛЬЧЕСКОГО ПРЕДПРИЯТИЯ}

Целью исследования является разработка эффективной бизнес-модели виноделия с использованием принципов маркетинга. Для решения задач используются методы анализа и синтеза, логического обобщения, аналогии, конкурентного сравнения. В статье обоснована эффеектиность производства вин из местного винограда для винзаводов Украины. Обоснование базируется на построении пяти уровней товара и потребительских ценностей. Пятый уровень - это вино, которое имеет уникальный стиль: свой характер, темперамент, выражает особенности местности, где произведено, и имеет направленые лечебные свойства благодаря максимальному содержанию полезных веществ из определенных сортов винограда и инновационной технологии. Локальное вино может быть сделано исключительно из собственного винограда. В работе проанализирован ряд украинских винодельческих хозяйств, где производят авторские вина и некоторые ассортиментные позиции, которые можно отнести к локальным винам.

На базе канвы бизнес-модели А. Остервальдера, была предложена бизнес-модель виноделия в формате шато. Разработаны миссия, цели и стратегии такого производства. Миссия заключается в производстве уникальных вин, возрождении традиций виноделия и культуры потребления вина в Украине. Определены целевая аудитория потребителей и конкурентные преимущества. Целесообразной признано конкурентную стратегию фокусирования на изготовлении локальных вин (local wine). Предложено маркетинговую стратегию роста - стратегия разработки нового товара. А именно - организация полного цикла изготовления столовых сухих белых вин из винограда нового селекционного поколения по авторским купажным схемам.

Рассмотрены основные тенденции в виноделии: на рынке виноматериалов происходят значительные изменения в предложении, а потребители начинают понимать важность качества. Исследования рынка показали, что производство локальных вин может стать конкурентным преимуществом украинских виноделов течение достаточно длительного периода времени. Конкурентные преимущества "шато", которое производит локальные вина, позволяют эффективно работать на национальном и международном рынках.

Ключевые слова: украинские предприятия, потребительская ценность, локальные вина, бизнес-модель шато, конкурентоспособность. 
Брайко М.Г.

старший викладач

кафедра маркетингу, підприємництва і торгівлі

E-mail: marina.g.braiko@gmail.com

Голубьонкова О.O.

кандидат економічних наук, доцент кафедра маркетингу, підприємництва і торгівлі Одеська національна академія харчових технологій

вул. Канатна, 112, м. Одеса, Україна, 65039

E-mail: lena.golubenkova@gmail.com
Солодова О.C. аспірант кафредра маркетингу, підприємництва і торгівлі E-mail: o.solodova@shabo.ua

\section{Брайко А.B.}

магістрант

кафедра туризму та дозвілля

Еразмус Мундус "Інновації в виноробному туризмі"

Університет Ровіра і Вергілія

вул. Хоанот Марторей 15, Віла-сека

Таррагона, Іспанія, 43480

E-mail: braikoanastasiia@gmail.com

\section{СТВОРЕННЯ ЛОКАЛЬНИХ ВИН ЯК ОДИН 3 НАПРЯМІВ ФОРМУВАННЯ КОНКУРЕНТНИХ ПЕРЕВАГ ВИНОРОБНОГО ПІДПРИЄМСТВА}

Метою дослідження $є$ розробка ефективної бізнес-моделі виноробства з використанням принципів маркетингу. Для вирішення завдань використовуються методи аналізу та синтезу, логічного узагальнення, аналогії, конкурентного порівняння. Стаття доводить ефективність виробництва вин з місцевого винограду для винзаводів України. Обґрунтування базується на побудові п'яти рівнів товарів та споживчих цінностей. П'ятий рівень - це вино, яке має унікальний стиль: свій характер, темперамент, виражає особливості місцевості, де вироблено, та має спрямовані лікувальні властивості завдяки максимальному вмісту корисних речовин з визначених сортів винограду та інноваційній технології. Локальне вино може бути зроблено виключно з власного винограду. В роботі проаналізовано ряд українських виноробних господарств, де виробляють авторські вина і деякі асортиментні позиції, які можна віднести до локальних вин.

На базі канви бізнес-моделі О. Остервальдера, було запропоновано бізнес-модель виноробства в форматі шато. Розроблено місію, цілі та стратегії такого виробництва. Місія полягає у виробництві унікальних вин, відродженні традицій виноробства та культури споживання вина в Україні. Визначено цільову аудиторію споживачів та конкурентні переваги. Доцільною визначено конкурентну стратегію фокусування на виготовленні локальних вин (local wine). Запропоновано маркетингову стратегію зростання - стратегію розробки нового товару. А саме - організація повного виробничого циклу виготовлення столових сухих білих вин з винограду нового селекційного покоління за авторськими купажними схемами.

Розглянуто основні тенденції у виноробстві: на ринку виноматеріалів відбуваються значні зміни в пропозиції, а споживачі починають розуміти важливість якості. Дослідження ринку показали, що виробництво локальних вин може стати конкурентною перевагою українських виноробів протягом досить тривалого періоду часу. Конкурентні переваги "шато", які виробляють локальні вина, дозволяють ефективно працювати на національному та міжнародному ринках.

Ключові слова: Українські підприємства, споживча цінність, локальні вина, бізнес-модель шато, конкурентоспроможність.

\section{Література}

1. Beysül Aytaçab, Thi-Hong-Van, Hoangab Cyrille Mandouab. Wine: To drink or invest in? A study of wine as an investment asset in French portfolios // Research in International Business and Finance. 2016. Vol. 36. P. 591614. doi.org/10.1016/j.ribaf.2015.03.001

2. Beysül Aytaç, Guillaume Coqueret, Cyrille Mandou. Herding behavior among wine investors // Economic Modelling. 2018. Vol. 68. P. 318-328. doi.org/10.1016/j.econmod.2017.07.022

3. Nedelcu A., Tătaru A., Subić J., Kuzman B. The Local Action Group, Local Sevelopment Model based on Community. Case Study-LGA "Land of Vineyards and Wine" Vrancea // Procedia Economics and Finance. 2015. Vol. 22. P. 706-715. doi.org/10.1016/S2212-5671(15)00290-7.

4. Schaffernicht M.FG. Causal attributions of vineyard executives - A mental model study of vineyard management // Wine Economics and Policy. 2017. Vol. 6 (2). P. 107-135. doi.org/10.1016/j.wep.2017.09.002 
5. Urso A., Timpanaro G., Caracciolo F., Cembalo L. Efficiency analysis of Italian wine producers // Wine Economics and Policy. 2018. Vol. 7 (1). P. 3-12. doi.org/10.1016/j.wep.2017.11.003

6. Hammervoll T., Mora P., Toften K. The financial crisis and the wine industry: The performance of niche firms versus mass-market firms // Wine Economics and Policy. 2014. Vol. 3(2). P. 108-114. doi.org/10.1016/j.wep.2014.11.001

7. Остервальдер А., Пинье И. Построение бизнес-моделей: настольная книга стратега иноватора / Пер. с англ. М.: Альпина Паблишер, 2011. - 288 с.

8. Kotler, P. Gertner, D. In Destination Brands. Oxford: Butterworth-Heinemann, 2011. 356 p.

9. Офіційний сайт "Вина Гулієвих»: [Веб-сайт]. Одеса, 2018. URL: http://www.gulievwine.com (дата звернення: 16.07.2018).

10. Офіційний сайт компанії «Beykush Winery» [Веб-сайт]. Очаків, 2018. URL: http://www.beykushwinery.com. (дата звернення: 16.07.2018).

11. Офіційний сайт компанії «Виноробне господарство Князя П.Н.Трубецького» [Веб-сайт]. Херсон, 2018. URL: http://www.vina-trubetskogo.com.ua (дата звернення: 16.07.2018).

12. Офіційний сайт компанії «Колоніст» [Веб-сайт]. Одеса, 2018. URL: http://www.kolonist.com.ua. (дата звернення: 16.07.2018). 16.07.2018).

13. Офіційний сайт компанії Шабо [Веб-сайт]. Одеса, 2018. URL: http://shabo.ua (дата звернення:

14. Solodova, O., Golubyonkova, O. Research of factors that influence the trademarks policy of an enterprise // Technology audit and production reserves. 2017. № 38. P. 34-39. doi: 10.15587/2312-8372.2017.119851

15. Брайко М.Г., Жихарєва Н.О. П’ять рівнів товару «вино тихе» // Ефективність політики економічного зростання: теорія, методологія та практика: матеріали Міжнародної науково-практичної конференції, Львів, 1928 січня 2017 р. / ГО «Львівська економічна фундація». Львів: ЛЕФ, 2017. С. $42-44$

Стаття надійшла 3.08.2018 Стаття прийнята до друку 17.08.2018 Доступно в мережі Internet 17.10.2018

Цитування згідно ДСТУ 8302:2015

Брайко М.Г., Солодова О.С., Голубьонкова О.О., Брайко А.В. Створення локальних вин як один з напрямів формування конкурентних переваг виноробного підприємства // Економіка харчової промисловості. 2018. Т. 10, Вип. 3. С. 3340; doi: 10.15673/fie.v10i3.1059

Cite as APA style citation

Braiko, M., Solodova, O., Golubyonkova, O., \& Braiko, A. (2018). Creation of local wines as a method of competitive advantages of the winery. Food Industry Economics, 10(3), 33-40; doi: 10.15673/fie.v10i3.1059. 